\title{
CAN METALINGUISTIC AWARENESS EXPLAIN A CONNECTION BETWEEN L1 LITERACY AND L2 PROFICIENCY LEVEL IN LITERATE ADULTS?
}

Donesca Cristina Puntel Xhafaj

Universidade Federal de Santa Catarina

Mailce Borges Mota

Universidade Federal de Santa Catarina/CNPq

\begin{abstract}
:
Recently, Bigelow, Delmas, Hansen, and Tarone (2006) argued that the differences in the oral performance of their L2 speakers (favoring the more literate ones) were probably due to their low level of metalinguistic awareness (which would be a consequence of their limited literacy). So as to contribute with evidence for this hypothesis, we collected data from 11 Brazilians, who performed tests of L1 literacy, L2 proficiency and L1 and L2 metalinguistic awareness (phonological, morphological, and syntactic) and a relationship between their L1 literacy and their L2 proficiency levels was, indeed, found. However, the role metalinguistic awareness (either in the L1 or the L2) plays in this relationship is not clear. While phonological awareness (in the L1 and in the
\end{abstract}

\begin{tabular}{|l|l|l|l|l|}
\hline Ilha do Desterro & Florianópolis & n 60 & p. 189- 245 & jan/jun 2011 \\
\hline
\end{tabular}


L2) was related to L1 literacy and L2 proficiency, morphological awareness (in the L1, only) and syntactic awareness (in the L2, only) were only related to L2 proficiency. Though these inconclusive results might be the artifact of limitations in some of the instruments used to collect data, this seems to be a fruitful line of research.

Keywords: literacy; metalinguistic awareness; L2 proficiency

\section{Introduction}

As Doughty and Long (2003) observed, with the acquisition ${ }^{1}$ of a second language (L2) becoming more and more common, monolingualism is now starting to be the exception. Still, though an array of variables have been investigated in relation to L2 development (e.g., language aptitude, learning styles, motivation, and personality, among others ${ }^{2}$ ), one possibly important relation that has been overlooked is that between first language (L1) literacy ${ }^{3}$ and L2 development.

Recently, Martha Bigelow and Elaine Tarone (e.g., Bigelow, Delmas, Hansen, \& Tarone, 2006; Tarone \& Bigelow, 2005; Tarone, Bigelow, \& Swierzbin, 2007) have proposed, based on theory and on empirical research, that one variable that might impact L2 learning is one's level of L1 literacy. According to the authors, this would be due to the fact that people with a limited level of L1 literacy will also probably have lower levels of metalinguistic awareness ${ }^{4}$ and this would impede them from, for example, noticing (Schmidt, 1990) the gap between their utterances and the recasts ${ }^{5}$ they receive from a native interlocutor. Since the Interaction Hypothesis (Long, 1991) proposes that this kind of feedback is one of the ways for a learner to restructure his/her interlanguage ${ }^{6}$, these low-literacy learners would be disadvantaged when coming to learn an L2. 
Still, despite the fact that Bigelow et al. (2006), Tarone et al. (2007), and Tarone \& Bigelow (2007) found empirical evidence which lends support to their claims, they did not measure their participants' level of metalinguistic awareness. Thus, so far, the link they established was between L1 literacy level and L2 oral production. The exact role (if any) metalinguistic awareness (either in the L1 or the L2) plays in this connection is yet unknown.

Moreover, the population investigated by Bigelow and Tarone were Somali immigrants (who were at the time living in the United States) with a very limited level of L1 literacy. Though Bigelow et al. imply that perhaps the differences in metalinguistic awareness they imagine to be present in their population will not extend to a literate population (p. 665), there is evidence that even among these learners there are differences in the level of L1 literacy. Just to cite one example, Oliveira and Oliveira (2007) had 138 undergraduate students take a cloze test (where the participants have to fill in the blanks left in a text after each 5th word of it has been omitted) and their accuracy was less than $50 \%$. Perhaps as compared to barelyliterate Somali immigrants all undergraduates will be highly literate but it might be better to look further into that before assuming such homogeneity in the literacy level of undergraduate students. Thus, another objective of the present endeavor was to investigate whether the relationship found between L1 literacy level and L2 performance would hold for undergraduate students.

In the remainder of this article, we first lay the rationale upon which the study was built. That will be followed by a description of the method employed to collect and analyze data. In the results and discussion section, each of the research questions will be answered in turn, and in the last section limitations and suggestions for further research will be addressed. 


\section{Literacy acquisition}

At present, many authors (e.g., Cerutti-Rizzatti, 2009; Kleiman, 1995; Rojo, 2009; Soares, 1998; Tfouni, 1995) claim that even people who have not been alphabetized, but who live in urban societies are letrados ${ }^{7}$. However, this is not the conception of literacy that we are adopting in the present research. As Soares puts it, if in the past the large number of illiterates/analfabetos was a problem in Brazil, now the problem are those people who, despite having mastered the written code, are not able to make use of this technology to cope with the demands constantly made by society (Soares, 1998, p. 20) which require, for instance, that people read and write texts in prose and identify and use information extracted from tables, maps and charts. In the present study, literacy is addressed as the formal learning of reading/writing ${ }^{8}$, something Rogers (2008) calls learning-conscious learning - and Rojo (2009) terms schooled literacy. In the present study, the operational definition of literacy will be that of the instrument judged suitable to asses literacy conceived as the formal learning of reading/writing-the PISA $^{9} 2000$ document, which defines reading literacy as "the capacity to understand, use and reflect on written texts, in order to achieve one's goals, to develop one's knowledge and potential, and to participate in society" (Organization for Economic Co-operation and Development [OECD], n.d., p.22).

Though there was a time when research which looked for a (general) cognitive impact ${ }^{10}$ for literacy acquisition was harshly criticized by social researchers (Kleiman, 1995; Soares, 1998), since the 1980s this view has been moderated (Biber, 2009) and proposals nowadays tend to look for links between specific aspects of reading/ writing (e.g., decoding) and their connection with other specific abilities (e.g., one's level phonological awareness). According to Mota (2007), though the discussion on the potential cognitive 
consequences of literacy acquisition is a hot ${ }^{11}$ (and open) issue, one point of agreement is the impact literacy acquisition has on metalinguistic awareness (and vice-versa).

On the one side, at least three kinds of metalinguistic abilities are thought to be important for reading/writing. Phonological awareness (PA) is expected to play a crucial role at the beginning stages of literacy acquisition (Bialystok \& Herman, 1999; Genesee, Lindholm-Leary, Saunders, \& Christian, 2006) though it will always be needed for the decoding of new words (Capovilla, Dias, \& Montiel, 2007; Cunha \& Capellini, 2009; Dias, 2006). Morphological awareness (MA) will probably be implicated in the role graphemes play in conveying meaning (Bryant, Nunes, \& Bindman, 2000; Ravid \& Tolchinsky, 2002) and in reading comprehension and pseudoword reading (Deacon \& Kirby, 2004). Finally, syntactic awareness (SA) might be useful when one relies on syntactic contextual clues so as to facilitate decoding/encoding (Bryant et al., 2000; Capovilla, Capovilla, \& Soares, 2004; Correa, 2005; Rego \& Buarque, 1987) and also when one uses the order of the words and the presence of function words and grammatical morphemes to extract meaning from the text (Bowey, 1986; Tunmer \& Bowey, 1984 in Cain, 2007).

At the same time, literacy acquisition is also likely to increase one's level of metalinguistic awareness. According to Ranta (2008), metalinguistic skills arise as a function of age and it is normal that children start analyzing language (and correcting themselves) as soon as they have established the connections between the symbols of the language and the reality (Karmiloff-Smith, 1979 in Kato, 1993). However, the process of detaching oneself from language, manipulating it and reflecting upon it does not happen naturally for all (Francis, 2006) and children of the same age have been known to vary in their degree of metalinguistic knowledge. Thus, there must be external factors at play. 
A good explanation of the way literacy acquisition might impact how much one reflects about language comes from Ehri (1985). According to her, when children learn to read printed language they acquire a spatial model of speech. That is, a transient phenomena, such as speech, can be held for longer in memory, and better organized, because now it also has a visual representation (besides the aural one). Though Ehri believes this kind of enhanced perception of speech can come to be through means other than exposure to print (e.g., through training), she believes it will be more difficult in those situations. It is also likely that the greater the experience with print, schooling, and development, the more this awareness will be explicit and the better the representations of speech will be organized (Karmiloff-Smith, 1992 in Ravid \& Tolchinsky, 2002). Yet, there is a lack of studies in which differences in the level of metalinguistic awareness are assessed in literate adults.

We will next review some of the empirical studies which have looked for a connection between PA, SA, and MA and literacy acquisition.

\subsection{Phonological awareness}

Though the directionality of the relationship between phonological awareness (PA) and literacy was once a subject of debate, nowadays, most scholars (e.g., Bialystok \& Herman, 1999; Capovilla et al., 2004; Mota \& Castro, 2007; Perfetti, Dyke, \& Hart 2001; Ravid \& Tolchinsky, 2002; Souza \& Bondini, 2007) seem to agree that, while PA is important for early literacy acquisition, literacy acquisition itself will lead to the development of more sophisticated levels of PA.

Apparently, the more basic level of PA, which involves supraphonemic awareness (i.e., the awareness of segments such as syllables 
and rhyme) is what enables us to conceive speech as a sequence of discrete segments (Read, Yun-Fei, Hong-Yin, \& Bao-Qing, 1986). However, being able to attend to, conceptualize, and manipulate sounds (especially at the level of the phoneme) is what it is really important (Bialystok \& Herman, 1999; Ehri, 1985), and this seems to be, indeed, a function of literacy acquisition. In what follows, some empirical studies which attempted to unveil the link between PA and literacy are reviewed.

One of the issues of interest as regards PA is whether its link with literacy development holds only for alphabetical languages or whether this ability (especially phonemic awareness) is also used in non-alphabetical ones. So far, findings are inconclusive, though they do seem to point to some role for alphabetical instruction in refining PA. On the one hand, Mann's (1986) Japanese participants had more difficulties than the American ones in a phonemedeletion task, Read at al's (1986) subjects who had been exposed to an alphabetic script could perform a task of phoneme synthesis and deletion much better than their peers, and McBride-Chang et al. (2005) review a number of studies were it was found that PA was important for reading even in Chinese (e.g., Ho \& Bryant, 1997; Hu \& Catts, 1998; McBride-Chang \& Ho, 2000 all in McBride-Chang et al., 2005). On the other hand, in McBride-Chang et al.s (2005) own study, PA was not found to be a predictor of reading in Chinese ${ }^{12}$. Additionally, one subject (out of 13 who repeated the PA task) in Read et al's research presented a great improvement in performance from the first to the second enactment of the task, indicating that even people who have not been exposed to an alphabetic script can gain awareness of phonemes with a little instruction.

Another group of studies, though not interested in differences between alphabetical and non-alphabetical languages, also looked 
for a connection between PA and reading/writing. Guimarães (2003), for example, not only found that her participants ( $4^{\text {th }}$ and $6^{\text {th }}$ graders), who had a history of difficulties with reading and writing, had greater difficulties in segmenting phonemically 2-syllable than 1-syllable words than beginning readers (from the $1^{\text {st }}$ grade) and typical $4^{\text {th }}$ and $6^{\text {th }}$ graders, but also found PA to correlate positively and significantly with reading and writing. Among the studies which were conducted at the beginning years of literacy, a positive correlation between $\mathrm{PA}$, reading, and writing was also found by Capovilla et al. (2004), Barrera and Maluf (2003), and Pestun (2005). In Mota, Anibal, and Lima (2008) a correlation was only found between PA and writing (reading was only found to be correlated with morphological awareness). Additionally, Capovilla et al. (2004), Capovilla et al. (2007), and Pestun (2005) found that their participants' performance on PA tasks increased with time (though only up to the $3^{\text {rd }}$ grade).

Similar to these studies, which were conducted with children, there was a line of studies which contrasted more- and less-literate adult subjects, and which also found a close link between PA and literacy development. Morais, Bertelson, Cary, and Alegria (1986), for example, found that ex-illiterates did better than illiterates, who only rarely reached the point of subsyllabic units, in a segmenting task. Reis and Castro-Caldas (1997) found that their illiterate participants had difficulties in repeating pseudowords (they could not deal with phonology detached from semantics), in identifying phonological similarities between a pair of words, and in producing nouns with a given phoneme (determined by the experimenter).

Dellatolas et al. (2003) compared high- and low-literacy adults and illiterate and literate children and found that the readers, in general (both children and adults), did better than the non-readers in 
all tasks, but especially in the speech-segmentation ones. Loureiro et al. (2003) compared the data from the adult participants in Dellatolas et al.'s study to the performance of 50 literate and educated controls and also found greater differences among the groups (readers, non-readers, and educated readers) in tasks which involved the segmentation of speech (phonological fluency and initial phoneme deletion). Kosmidis, Tsapkini, Folia, Vlahou, and Kiosseoglou (2004) found that their illiterate participants generated fewer words in a verbal fluency task than the literate/little-educated ones on both the semantic and the phonological tasks, and this was mainly due to their smaller clusters in the phonological test. Finally, Mota and Castro (2007) found marked differences between their illiterate group and the two literate ones (with more and less education) in their performance in a PA task. The general conclusion the authors arrived at is that literacy acquisition does impact metalinguistic awareness but, differently from what Loureiro et al's (2003) results hinted at, they concluded that, apparently, this effect does not continue with the increase in literacy (i.e., the more literate group did not perform much better than the group with low literacy ${ }^{13}$ ).

Another line of studies investigated whether PA could be a good predictor of later or concurrent reading/writing performance. In Plaza and Cohen (2003), PA contributed with $14 \%$ of variation in the performance in the reading and writing tasks once syntactic awareness (SA), auditory memory, and naming speed were partialled out. A similar result was found by Mahony, Singson, and Mann (2000), who found that PA contributed with $13 \%$ for reading, and by Godoy (2005) who established that the best predictor of word reading and spelling at the end of the $1^{\text {st }}$ grade was the participants' level of phonemic awareness at the end of the pre-school, explaining $21 \%$ of reading and $43.6 \%$ of writing. 
In Juel, Griffith, and Gough (1986) they found that ethnicity, IQ, and entering oral language skills contributed to phonemic awareness which, together with listening comprehension, showed to be a good predictor of year-end performance in spelling, word recognition, writing, and reading comprehension in the $1^{\text {st }}$ grade and, to a lesser extent, in the $2^{\text {nd }}$ grade. Wagner, Torgesen, and Rashotte's (1994) measures of phonological analysis and synthesis in kindergarten were good predictors of decoding in the $1^{\text {st }}$ grade, and the scores in the same measures in the $1^{\text {st }}$ grade were predictors of decoding in the $2^{\text {nd }}$ (though none of the variables made an independent contribution). Rego (1995), however, did not find the usual strong correlations between PA and reading, though she suspected that perhaps it was the efficiency of instruction (phonics method based on syllables) which diminished individual differences by the end of the $1^{\text {st }}$ grade.

In another longitudinal study, Lazo, Pumfrey, and Peers (1997) found an indirect impact of PA on reading and writing. Though the participants' scores in some of the PA, SA, print, and pragmatic tasks which were taken at time 1 were significant predictors of attainment in reading and spelling at time 4, this was because these skills helped pre-conventional reading and spelling and these latter variables predicted literacy levels at time 4. On the other hand, Nunes, Bryant and Bindman (1997) did not have much encouraging results regards the contribution of PA to spelling. Though they found that PA was a predictor of spelling in one experiment conducted, the pseudo-verbs they used had stems which were similar to real verbs, indicating that perhaps the correct spelling made by the participants was simply due to the use of analogy. Indeed, in another experiment, where the pseudoverbs were not similar to real ones, PA was not a predictor of spelling.

There were some studies which investigated the relationship between PA and literacy in bilinguals. Carlisle, Beeman, Davis, and 
Spharim (1999), for example, found that L2 PA made a significant contribution (6\%) to L2 reading, while Jongean, Verhoeven, and Siegel (2007) found that PA was important for reading and writing for both L1 and L2 speakers of English. In the same way, Caravolas, Volín, and Hulme (2005) found that PA was among the best predictors of reading speed, spelling, and reading comprehension in both English and Czech (a language with more transparent grapheme-phoneme relationships). In Swanson, Rosston, Gerber, and Solaris (2008) study, however, PA was not found to make a unique contribution to either English or Spanish reading.

The conclusion we draw from all these studies is that PA seems to be augmented after training in an alphabetical language and keeps increasing along the grades (at least until the $3^{\text {rd }}$ grade) and correlating with measures of reading and writing. Moreover, in some studies PA was found to be a good predictor of reading and/ or writing, both in the L1 and in the L2. However, evidence also points out to the fact that it is possible, though unlikely, apparently, to develop phonemic awareness even in the absence of instruction in an alphabetical language. Additionally, it is still unknown whether PA will continue to increase (beyond $3^{\text {rd }}$ grade) as literacy develops, and even if it will continue to be important and/or necessary for the reading/writing of literate adults.

We turn now to a review of the studies which have attempted to unveil the relationship between MA and literacy.

\subsection{Morphological awareness}

Mota (2007) explains that reading involves two principles-the phonographic (related to how letters and phonemes relate to each other) and the semiographic (related to how words are constituted from phonemes), with MA being associated to the acquisition of the 
second principle and PA to the first. However, since morphemes are made up of phonemes, it could be that MA the relationship MA has with reading is derivative of phonological abilities (Carlisle, 2006). Thus, one of the recurrent issues in the research on the link between MA and literacy is whether MA makes an independent contribution to reading beyond that of $\mathrm{PA}$. Evidence reviewed below indicates that MA does make an independent contribution to literacy and, at times, it is even greater than that of PA.

As it happens with PA, MA was also found to increase along the grades. Mota (2008), for example, found that, in 3 of the $6 \mathrm{MA}$ tasks which her participants completed, the $2^{\text {nd }}$ graders did better than the $1^{\text {st }}$ ones. The same was found by Mahony et al. (2000), Singson et al. (2000) (up to the $6^{\text {th }}$ grade, in both studies), Nagy, Berninger, Abbott, Vaughan, and Vermeulen (2003) (up to the $4^{\text {th }}$ grade), and Nagy, Berninger, and Abbot (2006) (up to the $9^{\text {th }}$ grade). In addition to that, in Mahony et al.s and Singson et al's studies MA made an independent contribution to reading (beyond that of PA). In Nagy et al.'s (2003) study MA was found to make an unique contribution, beyond that of PA, orthographic awareness, and vocabulary knowledge to reading comprehension for the $2^{\text {nd }}$ graders, but that did not happen for the $4^{\text {th }}$ graders (though MA was correlated to reading comprehension measures). As regards writing, MA was correlated to spelling in the $2^{\text {nd }}$ grade, but it did not make an independent contribution to it.

Differently from Nagy et al. (2003), in Nagy et al. (2006) MA did make an independent contribution to reading and writing (beyond that of vocabulary) in all grades investigated (from the $4^{\text {th }}$ to the $9^{\text {th }}$ ). In the Brazilian context, Mota, Anibal et al. (2008) had a similar finding, with MA contributing to the $1^{\text {st }}$ and $2^{\text {nd }}$ graders' performance on reading and writing tasks (beyond the contribution made by PA). 
In a longitudinal study, Nunes et al. (1997) found that their participants with more $\mathrm{MA}^{14}$ were also the ones who did better in spelling the "ed" morpheme at the end of regular pseudoverbs, being a predictor of spelling even after age, IQ, and phonological skills were controlled for ${ }^{15}$. However, as it was pointed out in relation to the PA findings in this study, part of the behavior of the participants might be explained by the fact that the pseudoverbs in the $1^{\text {st }}$ study were analogous to real verbs. Finally, in Deacon and Kirby's (2004) study, MA was found to contribute, though modestly ${ }^{16}$, to literacy beyond verbal and non-verbal intelligence, and PA.

What can be concluded as regards the relationship between MA and literacy is that there is an increase in MA as schooling progresses (at least until the $9^{\text {th }}$ grade). MA has shown to be correlated to both reading and writing and it is also a good predictor of these two skills, with this contribution holding even when the variables vocabulary knowledge, IQ, verbal and non-verbal intelligence, and PA are partialled out. In general, however, the role MA has in reading and writing appears to be smaller than that of PA).

The last of the three metalinguistic abilities under investigationsyntactic awareness-is addressed in the next subsection.

\subsection{Syntactic Awareness}

Cain (2007) observes that, though research linking syntactic awareness (SA) and literacy has been conducted for over 20 years, this relation is still not well-understood. In the Brazilian context, Guimarães (2003) states that the number of studies conducted investigating this relationship is still small and, thus, here also there is not an agreement on whether SA contributes or not to literacy and whether this is a reciprocal relationship. 
As it happens with PA and MA, SA also has been shown to increase along with the grades, but the findings are not conclusive. While Capovilla et al. (2004) found an increase in scores in SA tasks up to the $4^{\text {th }}$ grade, Bowey (1996), though having collected data from preparatory school up to the $5^{\text {th }}$ grade, found an increase only up to the $2^{\text {nd }}$ grade. In Bowey and in Barrera and Maluf (2003), SA was also found to be correlated to reading, and, in the case of the latter study, to spelling. Bowey also investigated whether SA was a good predictor of reading and, in a multiple regression analysis, found SA to contribute with 5\% to reading. Similarly, Plaza and Cohen (2003) found that both SA and naming speed (as well as the control variables PA and auditory memory) were related to both reading and writing, with SA making a contribution of $2 \%$ to literacy-related performance (beyond that of the other 3 variables).

Though, according to the studies reviewed above, it seems that SA does make an independent contribution for literacy development, Cain (2007) raised the issue that, perhaps, there could be other variables intervening in this relationship. In his study, despite the fact that the participants' performance on the SA tasks correlated with their performance on tests of reading ability, the performance on neither of the tasks showed to be a predictor of reading comprehension. On the other hand, Lazo et al. (1997) found that SA measures taken when their participants were in nursery school were predictors of their pre-conventional reading and spelling, which, in turn, predicted attainment in reading and spelling at the end of $1^{\text {st }}$ grade. In another longitudinal study, Rego (1995) found that SA was significantly correlated with word reading in context and reading comprehension and, after age and verbal working memory were controlled, it was efficient in explaining a significant percentage of variance in the word reading in context task. 
Another line of research in SA compared the performance of poor and good readers, contributing with evidence for a reciprocal relationship between SA and reading. Guthrie (1973 in Guimarães, 2003) found that good readers were better at choosing, from 3 alternatives, the adequate one to fill in the gaps in a cloze test. Tunmer, Nesdale, and Wright (1987 in Guimarães, 2003) also found that good readers (even when younger and having received less instruction than the poor readers) did better than the poor readers in two SA tasks (oral cloze and word order). Nation and Snowling (2000), in turn, found that normal readers did better in a word-order correction task than the poor readers, regardless of the difficulty of the sentences. However, Bryant, Nunes, and Bindman (1997) had different findings. In their case, the poor readers (who had an equivalent decoding ability to the control ones after having been for longer in school) did better in the SA tasks than the good readers. Finally, in the Brazilian context, Guimarães (2003) also found that poor readers had less SA than the good ones.

In studies with bilinguals, Swanson et al. (2008) showed that the correlations between the English reading measures were stronger with the SA than the PA English measures. As for Spanish reading, SA made unique contributions to word identification and to reading comprehension. Similarly, in Jongean et al.s (2007) experiment, SA was found to be the best predictor of spelling and word reading in upper grades $\left(3^{\text {rd }}\right.$ and $\left.4^{\text {th }}\right)$ for the L1 speakers of English.

In the only study we found linking SA and literacy in which the informants were monolingual adults-Mota and Castro (2007)though there were significant differences in the performances of all groups (illiterates, low-literacy, and high-literacy) in the SA tasks, as it happened for PA, these differences were greater between the illiterate and the 2 literate groups (which had similar performances). 
Apparently, the conclusions we can draw for SA are less clear than those for PA and MA. First, it seems that SA increases with the school grade. However, Bowey (1986) only found this increase up to the $2^{\text {nd }}$ grade (and only for one of his SA tasks). Moreover, though illiterates were found to perform worse than literates in SA tasks, no significant differences were found between moreand less-literate subjects. Second, SA seems to be linked to both reading and writing and its contribution seems to be independent from that of vocabulary knowledge, PA, or working memory capacity. However, its contribution, in general, is modest and it was not found in all studies. Third, good readers have shown to have a better performance than poor ones in tasks of SA. However, in Bryant et al. (1997), they actually found that the poor readers (but more schooled) had more SA than the good ones. Finally, the issue of reciprocity between the development of SA and literacy is still argued and speculated (Cain, 2007).

\subsection{L1 and L2 metalinguistic awareness}

In addition to the link between literacy development and metalinguistic awareness, there are studies which found L1 metalinguistic awareness (mainly PA) to be connected to L2 metalinguistic awareness. The transfer of PA from the L1 to the L2 was found by Bialystok, Luk, and Kwan (2005), Cheung, Chen, Lai, Wong, and Hills (2001), Chikamatsu (1996), Cisero and Royer (1995), Hamada and Koda (1992), McBride-Chang et al. (2005), Swanson et al. (2008), and Verhoeven (1994).

Some studies (e.g., Bialystok et al., 2005; Cheung et al., 2001; Gottardo, Yan, Siegel, \& Wade-Wolley, 2001; Hamada \& Koda, 2008) also found that L1 PA aided L2 reading. Durgunoğlu, Nagy, and Hancin-Bhatt (1993), for example, found that their participants' 
L1 PA score (Spanish) was significantly correlated to English word reading. Their conclusion was that once a child reflects on the components of a language, this awareness can also be applied to another language; thus, PA does not develop specifically for each language. In Schwartz, Share, Leikin, and Kozminsky's (2007) study they found that the L2 literacy acquisition of their 26 biliterate bilinguals (Russian and Hebrew) was aided by the transfer of PA from the more phonologically complex L1 (Russian) to the L2 (Hebrew). According to the authors, the benefits were not only due to a generalized insight of the alphabetic principle but because the L1 had an orthography representing a complex syllabic structure.

Finally, there have been studies which found that transfer can also take place from the L2 to the L1. Ganschow and Sparks (1995) explicitly taught L2 (Spanish) phonology and syntax to their participants (high risk L2 learners) for one year and found that they also improved their word identification, phoneme segmentation, and pseudoword recognition in the L1 (English). Along the same lines, Roberts and Corbett (1997 in Riches \& Genesee, 2006) showed that instruction in the L2 (English) PA improved L1 (Hmong) PA.

As regards the possibility of transfer of MA, Koda (2000) found that her Korean participants used their skills of intraword analysis developed in the L1 when performing in English (a language which, despite being alphabetical, has a morphological system which is structurally and functionally comparable to Korean). They were faster, though not more accurate, than the Chinese participants when analyzing the structure of English words (especially for lowsaliency ${ }^{17}$ ones). At the same time, Koda also found that the Chinese participants capitalized on their L1 skills when performing a task which required the integration of morphological (prefix) and wordexternal information (context), being faster and more accurate than 
the Koreans. The conclusion Koda arrives at is that depending on the similarity between the $\mathrm{L} 1$ and the $\mathrm{L} 2$ processes, $\mathrm{L} 2$ experience will be more or less important for the development of $\mathrm{L} 2$ intraword awareness.

As regards SA, evidence for its transfer from the L1 to the L2 comes, for example, from Durgunoğlu, Mir, and Ariño-Martí (2002 in Durgunoğlu, 2002) who found that the performance of their participants in an error correction task in their L1 (Spanish) was correlated to their performance in the same task in the L2 (English). Verhoeven (1994), already partially reviewed above, also found transfer for grammatical abilities (besides pragmatic and phonological), since the measures of L1 grammar were strong concurrent predictors of performance on tasks assessing L2 grammar.

What we can conclude from the studies reviewed in this subsection is that PA is probably transferred across languages. As regards MA and SA, because of the limited number of studies we have found, no conclusions can be arrived at. Apparently, transfer of both of these abilities is possible (since there is at least some evidence for it), but there is not enough empirical evidence, so far, for us to make this claim. According to Verhoeven (1994), the development of lexical and syntactic skills in the L1 and the L2 seem to be autonomous.

In the final part of this review we turn to the few studies we have found which have attempted to verify how different levels of metalinguistic awareness in the L1 might play a role in L2 learning.

\section{Metalinguistic awareness, and L2 learning}

Although Tarone and Bigelow argued that no one had ever looked at the potential impact lower levels of metalinguistic awareness could have on the process of learning an L2, this is not entirely true. The group of Sparks and Ganschow (see below) has 
done that. The difference here is that their focus is on learners which have difficulties in learning an L2, rather than typical learners.

Sparks and Ganschow (1991) present a proposal-the Linguistic Coding Deficit Hypothesis-according to which phonological abilities (or disabilities, in their perspective) are thought to be the main cause for difficulties in L2 learning (Ganschow et al., 1994; Sparks et al., 1989 both in Sparks \& Ganschow, 1991; Ganschow, Sparks, Javorsky, Pohlman, \& Bishop-Marbury, 1992 in Sparks \& Ganschow, 1993; Sparks et al., 1998; Sparks, Ganschow, Javorsky, Pohlman, \& Patton, 1992). Apparently, this difficulty is not easily perceived in the L1 due to the strategies used by learners to compensate for these shortcomings, but when these people aim at acquiring an L2 (i.e., a new linguistic coding system altogether), such strategies are not that helpful (Sparks \& Ganschow, 1991). Studies conducted outside Sparks and Ganschow's group of research also lend power to this prediction.

Meschyan and Hernandez (2002), for example, found that L1 decoding skills were transferred to the L2, since good L1 decoders were also good L2 decoders. Moreover, L2 decoding skill was a good predictor of L2 competence in the first quarter of a Spanish course. Dufva and Voeten (1999) in their study of $1701^{\text {st }}$ graders from Finland who were learning English as an L2 found that the best predictor of English proficiency was $2^{\text {nd }}$ grade L1 word recognition skill with reading comprehension and phonological memory having a smaller impact. Thus, as expected, L1 word recognition skills did predict L2 learning (for them, these results are in accordance with the linguistic coding deficit hypothesis).

Finally, Ranta (2002) also found a connection between metalinguistic awareness and L2 learning. She collected data with 150 children from Canada, L1 speakers of French, who were 
being instructed intensively in English and, at first, her results seemed disappointing since the participants' performance in the L1 metalinguistic task ${ }^{18}$ accounted for $16 \%$ or less ${ }^{19}$ of the variance in L2 measures. Additionally, in a Principal Component Analysis, Ranta found that L1 metalinguistic knowledge and performance on post-instruction L2 proficiency tests did not load on the same factor. However, a link between metalinguistic awareness and L2 learning was established through a cluster analysis where it was possible to observe one cluster with learners who did well in the L1 metalinguistic task and had a good L2 performance and another cluster which contained learners who did poorly in both of these tasks. Thus, for the strongest and weakest learners in this population, metalinguistic awareness did predict their degree of success in L2 learning.

Putting it all together, while there have been studies which have found that literacy acquisition (i.e., alphabetization) will increase one's metalinguistic abilities (PA, SA, and MA), it is yet unknown whether further experience with print will continue to refine these abilities (even if to a smaller extent than this first impact). It is possible to hypothesize that as one continues dealing with print and with more complex texts (involving more complex syntax and a richer and wider vocabulary), the more his/her metalinguistic abilities will increase and the higher the literacy level of this individual will be. Since metalinguistic abilities have been found to impact L2 learning, one might expect that the learners who have a higher L1 literacy level and/or more metalinguistic awareness also will be the most successful learners of an L2 (if all the other variables involved in the process of L2 development could be held constant, of course). From this rationale, the following research questions were posed:

1. Is learners' L1 literacy level a predictor of their L1 metalinguistic awareness level? 
2. Is their L1 metalinguistic awareness level a predictor of their L2 metalinguistic awareness level?

3. Does their level of L1 literacy, L1 metalinguistic awareness, and/or L2 metalinguistic awareness predict their level of L2 proficiency?

In the next section, the method employed to collect data to answer these questions is described.

\section{Method}

\subsection{Participants and context}

Students from the $1^{\text {st }}$ semester of the English course (Expressão Oral e Gramática em Lingua Inglesa I) at the Letras/Inglês Program at Universidade Federal de Santa Catarina were contacted on May, 14 , 2009. Eleven students ( 8 females and 3 males) in the group accepted to contribute with data for the present study after reading and signing a consent form. The reason for the choice of participants was based on the fact that, according to the results of Harley and Hart's (2002) and Ranta's (2002) studies, being able to analyze language is more important for older (than younger) learners and in instructional settings.

Participants' ages ranged from 17 to 41 years (with a mean of 23.09) and, according to their answers to a literacy practices questionnaire, most of them (10), besides having studied English in the regular school also studied somewhere else (in public or private language courses or at home, by themselves). Only one participant had been to an English-speaking country (for 30 days). As regards the literacy materials they reported to have at home and their literacy practices, they were a fairly homogeneous group. Most had all sorts of reading materials at home and also usually read them. None of them said to dislike either reading or writing: 8 of them stated they 
liked reading a lot and 6 said to enjoy writing a lot. Most (10) said to find reading and writing essential for someone's development and 10 and 9 participants, respectively, reported to read and write without any difficulties. The other(s) reported having some difficulty. Finally, most had parents who could read and write well.

\subsection{Instruments}

\subsubsection{L1 literacy assessment-the PISA test}

In the present study we used a modified version of the reading section of the PISA 2000 test. This is a pen-and-paper test of reading which has both multiple-choice and open questions and, besides texts, includes pictures, graphs and/or tables. According to the test description provided by OECD (n.d.), "Rather than examin[ing] mastery of specific school curricula, PISA looks at students' ability to apply knowledge and skills in key subject areas and to analyze, reason and communicate effectively as they examine, interpret and solve problems"20.

Though the PISA test has been developed to be used with 15 year-olds, after looking through the kinds of texts and questions which comprised the instrument, we speculated that, perhaps, it would not be unfit for beginning college students. If the kind of literacy we want to assess requires that a person "respond adequately to the intense social demand for a broad and diverse use of reading and writing" (Soares, 1998, p. 20), PISA indeed seems to be adequate since it requires that test-takers identify and recover information, interpret texts (i.e., construct meaning, make inferences) and reflect upon form and content of a given text (including a critical evaluation of the information contained in the text and hypothesis building).

Since it was not possible to gain access to an actual booklet ${ }^{21}$ from the PISA 2000 test, a modified version was assembled using 
some of the sample questions which OECD makes public. PISA uses different text formats, $2 / 3$ of them being continuous (i.e., they are presented in a block of text and are not or do not contain graphs, charts, tables, diagrams). Thus, from the 11 texts available from the PISA 2000 edition of the test, we selected all the 5 continuous texts available and 3 non-continuous. The criterion used for the selection of the texts was based on the formats more commonly used in the assessment. This way, the 3 non-continuous texts chosen were a graph, a table, and a diagram. This procedure left us with 8 texts and 55 questions.

The next step taken was to verify whether the questions selected reflected, as accurately as possible, the PISA structure. In the PISA test there are 5 different processes which are assessed: retrieving information, broad understanding, developing an interpretation, reflecting on content and reflecting on form. The first 3 processes (reading using information from the text) are assessed in $70 \%$ of the questions and the last 2 (reflecting drawing upon outside knowledge) are assessed in the other $30 \%$. So as to achieve this balance, 7 questions were eliminated. In the end, the test had 48 questions (24 open, 24 closed), in 5 continuous and 3 non-continuous texts, with 34 of the questions assessing reading (21\% - 10 questions- for retrieving information, 21\% - 10 questions- for broad understanding, 29\% -14 questions- for interpreting) and 14 questions assessing reflection (19\% -9 questions- for reflecting on content and 10\% -5 questionsfor reflecting on form).

The actual PISA 2000 booklets contained between 55 and 67 questions (to be completed in 2 hours) and since the adaptation used in the present study contained only 48 questions, the time allowed for the test was also reduced, to $1 \mathrm{~h} 40 \mathrm{~min}$. This reduction allowed the participants to complete the test in two consecutive periods of classes 
(each period lasts $50 \mathrm{~min}$.). More information about the L1 literacy level of the participants was gathered through a literacy practices questionnaire (see section 4.2.6).

\subsubsection{L2 proficiency assessment-The Cambridge's KET}

The Key English Test (KET) is a test developed by the University of Cambridge Local Examinations Syndicate (UCLES) to offer a basic qualification in English to learners of all nationalities and ages and its main aim is to assess the ability one has to communicate effectively in English. The test has three papers ${ }^{22}$ : reading and writing, listening, and speaking and the final mark of a test-taker is an aggregate of these three marks, with the Reading and Writing mark contributing with $50 \%$ of the score, and the Listening mark and the Speaking mark contributing with $25 \%$ each. The main reason for the choice of KET was due to its level (A2) in the Council of Europe Common European Framework of Reference (CEFR) for Languages being the same level as the book the students followed in the first English course in the Letras/Inglês undergraduate program-Interchange Third Edition (Richards, Hull, \& Proctor, 2004)-at the time of data collection.

The version of the test used for data collection was one of the 2 versions which are available at the Cambridge website and the procedures followed the standard ones recommended in the KET handbook. There was one difference, however, as regards the Speaking paper. In the assessment made by the UCLES, during the assessment of oral language, a candidate will interact both with an examiner and with another candidate. For practical reasons, however, in this data collection the participant only interacted with the researcher collecting the data. Moreover, in the actual test, besides the examiner who interacts with the test-takers, another examiner is present in the room and awards marks. In the case of the present study, 
participants' performances were recorded and, afterwards, marked, by the same researcher, according to the instructions presented in the KET handbook.

\subsubsection{Phonological awareness assessment-Phoneme segmentation and phoneme transposition}

One challenge in developing the tests to assess metalinguistic abilities in the present study was the fact that most studies of metalinguistic abilities have been conducted either with children (e.g., Capovilla et al, 2004; Deacon \& Kirby, 2004; Mota, Anibal et al., 2008; Nunes et al., 1997) or with illiterate or little-literate adults (e.g., Dellatolas et al., 2003; Read et al., 1986). In the case of this study, since we were dealing with literate adults, a decision was made to use the most difficult kinds of PA tests, which are the ones which deal with awareness at the level of the phoneme (Capovilla et al., 2007).

In the phoneme segmentation task, participants listened once to a given word (e.g., bag) and then had to reproduce each of its phonemes in isolation (b-a-g). In the phoneme transposition task participants listened once to a pair of words (e.g., black cat) and then had to switch the initial phoneme of each of the words between them (clack bat).

The stimuli used for the English version of both PA tasks were taken from Holm and Dodd's (1996) study and the Portuguese version was built to mirror the English one as closely as possible, with some of the words taken from Marchetti (2008) and Lasch (2008). Both the English and the Portuguese versions had 4 three-phoneme words, 4 four-phoneme words and 2 five-phoneme words and there was an attempt to have words with a variety of vowel and consonant sounds. As regards the phoneme transposition task in Portuguese, the only study we found to have a task similar to the spoonerism one was Pereira's (2008); however, the stimuli seemed to be too easy (only 
involving CV words) when compared to the English stimuli. Thus some of the $\mathrm{CV}$ words used by Pereira were kept but others were added so as to make this task as similar as possible to the English version in design. In the end, each of the phoneme transposition versions of the task (the English and the Portuguese one) had the following pairs (according to the phoneme order): $\mathrm{CV}-\mathrm{CV}$; $\mathrm{CVV}-$ CVV; CCV-CCV; DigraphV-DigraphV; CV-CVV; CV-CCV; CVDigraphV; CVV-CV; CCV-CV; and DigraphV-CV, which were presented in a random order.

The stimuli for all four PA tasks was digitally recorded and presented aurally, only, to the participants. Each of these tasks was comprised of one model, 2 training trials (with feedback), and 10 test trials (without feedback). The tasks were researcher-controlled and after each word was played, the researcher would pause the recording and the participant could take as long as s/he wanted to produce a response. All participants were encouraged to attempt to answer all questions but they could choose to skip one (or more) if they felt uncomfortable with making an attempt. Participants' responses were recorded in a digital file for posterior analyses.

\subsubsection{Morphological awareness assessment-morpho-} semantic decision and morpho-semantic association

Since there is some discussion on whether grammaticality judgment tasks are only assessing syntax or whether they are also assessing inflectional ${ }^{23}$ morphology, the test of MA only assessed derivational ${ }^{24}$ morphology. In the morpho-semantic decision task, participants listened to a set of three words once (e.g., instrutor/ feitor/major) and then had to decide whether the second or the third word belonged to the same morphological family as the first. In the case of the example, the second word (feitor) is from the same 
morphological family as the first (instrutor) because both of them are root + suffix -or (i.e., the equivalent to "the person who..."). In the morphological association task, the participants listened to a pair of words (e.g., banda/bandeira) and had to decide whether these two words belonged to the same morphological family or not.

In the English version of the morphological decision task, the first 5 stimuli were taken from Koda's (2000) study and the last 5 items were adapted from Singson et al's (2000) study. For the Portuguese version of the test we used the stimuli developed by Besse, Vidigal de Paula, and Gombert (personal communication in April, 2009). In English, the words varied between 5 and 11 characters and in Portuguese between 5 and 12. In each of the versions of the tasks 5 prefixes and 5 suffixes were used. In Portuguese des- was used 3 times and $r e$ - was used twice, -eiro was also used twice and -or was used 3 times. In English re-was used 3 times and in-was used twice; -ance and -en were used twice each and -tion was used once.

We did not find any studies which had used a morphological association task in English, thus, we created our own stimuli with support from the stimuli used by Singson et al. (2000). The stimuli used in the Portuguese version of this task were also taken from Besse et al. (personal communication in April, 2009). In English, the words varied between 4 and 11 characters in length; in Portuguese, between 4 and 9 . The words were read by the same readers of the PA tasks stimuli and each task had one model, one training trial (with feedback) and 10 test trials (without feedback).

The procedures for the test were the same as for the PA tasks, with the difference that, this time, rather than each word being played at a time, each set of words (3 or 2) was played before the researcher stopped the recording for the participant to give an answer. Responses could be in the language the participant felt more 
comfortable with. Possibly due to their limited command of the English language, participants usually replied in Portuguese.

\subsubsection{Syntactic awareness assessment-error correction and error replication}

Though Nation and Snowling (2000) say one of the most common tests of SA is grammaticality judgment - where test-takers read or hear sentences and have to decide whether they have deviations as regards grammar (e.g., Capovilla et al., 2004; Jongean et al., 2007; Mota \& Castro, 2007; Schwartz et al., 2007) tests of grammaticality judgment may not be efficient in capturing individual differences since, as Mota, Gontijo et al. (2008) pointed out, they are not very demanding cognitively and test-takers might get correct answers simply by chance. Apparently, tests of error identification and correction are more cognitively demanding since they require more control (Mota, Gontijo et al., 2008).

Thus, the first part of the SA test was an error correction task. In this task, participants had to decide whether the 10 sentences presented in writing, one at a time (e.g., She doesn't loves Peter), on the screen of a computer, were grammatical or not. The English stimuli used in this task were taken from Alves (2008), Bowey (2005), and Jongean et al. (2007). For the Portuguese task, we looked for sites with the most common difficulties Brazilian Portuguese speakers have as regards grammar, and selected the stimuli from their examples.

Since in a review of the tests most commonly used to assess morphosyntactic ${ }^{25}$ awareness, Correa (2005) concludes that one test that does not have as many problems as the others is the test of error replication, this was the second task of the SA test. In this task, first the participant was shown, on a computer screen, a sentence with some grammatical deviation which s/he had to identify. After the response, another sentence was shown, with a similar structure but 
without any deviations and the instruction for the participant, then, was to replicate the error of the first sentence in the second. In other words, to transform the correct sentence in such a way that it carried the same grammatical deviation as the sentence first presented.

The English and the Portuguese stimuli for the error replication tests were taken from the same studies and websites used as sources for the error correction task. The kinds of deviations, in both languages and tasks, were in verb agreement (number, tense) and use of prepositions. In English, there was also a deviation in the use of the auxiliary verb and in the genitive case. In Portuguese, there was one case of noun agreement as regards gender. The English sentences ranged from 4 to 10 words in length and the Portuguese ones from 3 to 10 words.

Once again, the procedures were very similar to the ones adopted for the previous tests. Besides the modeling done by the researcher, in the error correction task participants had the opportunity to make two training trials (with feedback) before commencing the test trials (without feedback) and in the error replication task they had one training trial (with feedback). The greatest difference between the SA tasks and the other two metalinguistic tasks was that, in this case, the stimuli rather than being aural was written. This measure was taken so as not to overload participants' working memory with the (sometimes lengthy) sentences. Sentences were presented one at the time (font Arial, size 48) on a computer screen and remained there while the participant thought about his/her answer. As in the other tests, participants were encouraged to try and provide an answer even when they were not sure about the correctness of their response.

\subsubsection{Questionnaires and interviews}

Since this was a pilot study, one of our interests was in the adequacy of the tasks for the population we intended to investigate in 
a further study. For this reason, after each of the tests the participants took, they were asked their opinion about it. The results as regards these questions will be published elsewhere. Two other questionnaires were completed by the participants-a profile questionnaire (to gather information about participants' L2 learning history and the contact they had had or were having with the L2 at the time data were collected) and a literacy practices questionnaire.

The literacy practices questionnaire was adapted from a questionnaire developed by Terra (2009), who, in turn, had the Indicador Nacional de Alfabetismo Funcional as a basis. This questionnaire consisted of 6 questions. The first 2 were related to the kinds of reading materials the participants possessed at home and the frequency with which they read a number of different text genres. The following 3 questions were about their beliefs about reading and writing, their reading and writing ability, and also how much they enjoyed engaging in these kinds of activity (reading and writing). The final question was about the literacy level of their parents.

\subsection{Procedures for data collection and analysis}

The procedures adopted for data collection and analysis were the following.

The first test taken by the participants was the listening, reading and writing sections of the $\mathrm{L} 2$ proficiency test (Cambridge's KET), which was administered during class hours in their regular classroom. In the same week, the L1 literacy test was applied. After these 2 tests were completed, in individual sessions, each participant performed 4 tasks-3 metalinguistic awareness tests (PA, MA, and SA tasks in a counterbalanced order) in the L2-English -- and the L2 oral proficiency paper of the KET. In the final individual session, the participants did the L1 metalinguistic awareness tasks. 
The profile questionnaire and the literacy practices questionnaire were given to the participants on the day of the L1 literacy test. Questions about the L1 literacy test and the L2 proficiency test appeared in the final sheet of each of these tests and interviews about the metalinguistic awareness tasks were conducted after each test was completed.

Data was analyzed qualitatively (to ensure that the population contributing with data had a similar enough profile) and quantitatively (to answer the 3 research questions). Participants' responses in the L2 proficiency test and in the L1 literacy test were corrected by the researcher according to the booklets provided with the tests. For the metalinguistic awareness tests, participants' responses were transcribed and scored by the researcher.

To answer the research questions, after obtaining the descriptive statistics and establishing that the scores were normally distributed for all tasks in all tests, the researcher employed linear regressions to assess the predictive power of the variables. The $\alpha$ level was set at .05 . Unfortunately, there was loss of data for one participant in the L1 metalinguistic awareness tasks, thus, in some analyses the number of participants is only 10 . In the following section, the results obtained will be discussed.

\section{Results and discussion}

\subsection{L1 literacy and L1 metalinguistic awareness}

Linear regressions were run to verify whether the scores participants got in the L1 literacy test (PISA) were good predictors of their level of L1 metalinguistic awareness. This was an exploratory research question since what has been most commonly found in studies is that metalinguistic awareness is a good predictor of 
reading proficiency (e.g., Caravolas et al., 2005; Jongean et al., 2007; Schwartz et al., 2007; Souza \& Bondini, 2007; Sparks, Patton, Ganschow, Humbach, \& Javorsky, 2008). However, since there have been studies which found that metalinguistic awareness continues to increase along with literacy, we speculated that, perhaps, the more experience one has had with the written mode, the more one's metalinguistic abilities have increased. Additionally, this increase would continue up to a high level of literacy, even though we would expect any enhancement to be much less marked than the one that has commonly been observed at the time of literacy acquisition.

However, the results obtained lend little support to this relationship (at least as regards the directionality of the relationship ${ }^{26}$ ) since participants' L1 literacy level was a unique predictor (58.1\%) for the participants' performance in only one L1 metalinguistic awareness task-phonological transposition $(F=11.08 ; p<.05)$.

The fact that the literacy level failed to predict $S A$ and MA levels is not totally unexpected, however. As regards SA, though in Capovilla et al. (2007) they found that SA increased and was correlated to their participants' literacy level up to the $4^{\text {th }}$ grade, in Jongean et al's (2007) study, though they collected data up to the $4^{\text {th }}$ grade, they found an increase in SA only up to the $3^{\text {rd }}$. In Bowey (1986), though data was collected up to the $5^{\text {th }}$ grade, an improvement in the performance of the participants in tasks of SA was only found up to the $2^{\text {nd }}$ grade. Thus, it might be that, indeed, further experience with print does not have such an impact in SA.

For MA, however, Nagy et al. (2006) found that scores in an MA task were good predictors of reading comprehension even at the $9^{\text {th }}$ grade. Still, in this case the directionality of the relationship was the other way around. Moreover, at least one of the MA tasks used in the present research seems to have been too easy for the participants. The 
means in the morpho-semantic decision task was 6.2 (out of 10), but in the morpho-semantic association task it was 9.1. Thus, it appears that this second MA task failed to capture individual differences among the participants as regards MA level. If we disregard possible limitations in the MA test, one reason that might explain the lack of relationship between these variables is the impact of formal instruction. As mentioned in the review of the literature, Rego (1995) attributed the lack of correlation between her participants' scores in a PA task and their performance in a reading task to the effectiveness of instruction (alphabetization) in a phonics method. Thus, formal instruction on morphological aspects of Portuguese might have diminished the potential differences in the level of MA participants had before instruction. Additionally, this might have also made this task familiar to the participants. In the interviews conducted with the participants at the end of the tests, 4 of them mentioned that the MA tests, especially in Portuguese, were not difficult and, among the reasons, 2 participants mentioned the fact that we are used to learning about word families in school.

Another point to be kept in mind when interpreting the results obtained for research question one is the possible inadequacy of the instrument used to assess L1 literacy. As described in the method section, the version of the PISA 2000 test used in the present investigation was an adaptation, based on the texts and questions OECD makes it available at their website. As previously explained in the method section, because the test had fewer questions (48) than what is common in the official PISA testing (between 55 and 67), the time allowed for test completion was shortened in 20 minutes, from $2 \mathrm{~h}$ to $1 \mathrm{~h} 40 \mathrm{~min}$. However, probably due to some texts being quite lengthy, most participants (6 out of 11) did not manage to finish it in time $e^{27}$. It could be argued, of course, that probably the ones who did 
finish it indeed have higher levels of literacy when compared to the others who took longer to read the texts and answer the questions; but, at this point, arguing for that would be just speculation.

Thus, the answer to research question one, which asked whether the L1 literacy level of college students who are beginning learners of English as an L2 was a predictor of their L1 metalinguistic awareness level, is: only in part. It does seem that PA and literacy are linked (as it has been repeatedly found in previous studies) and that, apparently, this link continues beyond the beginning years of reading. However, due to the limitations in the task used to assess L1 literacy, no firm conclusions can be drawn. In the next subsection, the results related to research question 2 are presented.

\subsection{L1 and L2 metalinguistic awareness}

There have been a number of studies, as reviewed above, which have contributed with evidence for the crosslinguistic transfer of PA (both from the L1 to the L2 and from the L2 to the L1). However, so far we have found only three studies which have attempted to verify whether such transfer also happens for other metalinguistic abilities such as the syntactic and the morphological ones. Once again, linear regressions were run to check whether the participants' level of L1 metalinguistic awareness could be a good predictor of their L2 level of metalinguistic awareness.

As regards PA, for both parts of the test, participants' scores in the L1 version was a unique predictor of their scores in the L2 version. Participants' scores in the L1 phonological segmentation task predicted $45.6 \%$ of their scores in the same task in the L2 ( $F=$ $6.69 p<.05)$ and their scores in the L1 phonological transposition task predicted $40.4 \%$ of their scores in the L2 version of the task $(F=5.42 p<.05)$. Though the phonological segmentation task seems 
to have been a little too demanding for the test-takers (the means were 4.5 in Portuguese and 2.64 in English-out of 10), it appears that, nevertheless, the ones who had a better performance in the L1 version of the test also managed to do well in its L2 version. This result is in line with the findings of Bialystok et al. (2005), Chikamatsu (1996), Cheung et al. (2001), Cisero and Royer (1995), Hamada and Koda (1992), McBride-Chang et al. (2005), Swanson et al. (2008), and Verhoeven (1994). According to Bialystok (2007), the empirical evidence we have nowadays as regards the transfer of PA seems to support the view that PA relies mostly on general cognitive abilities and, thus, can easily transfer across languages. According to Francis (2006), apparently, the mechanism responsible for linking phonological structures to their orthographic representations is readily available to be used, irrespective of the language of the text (at least when the two languages have the same type of orthography, e.g., alphabetic) and this is what the results for the transfer of PA in the present study seem to be confirming.

As regards MA, for the morphological decision task, significance was only approached $(p=.055)$. However, had the relationship been significant, participants' L1 scores would have been effective in predicting $38.7 \%$ of their performance in the $\mathrm{L} 2$ version of the task $(F=5.04)$. The same was not true for the scores in the morphological association task. One possible reason for that would be the ceiling effect present in the participants' scores in the L1 version of the morphological association task, as mentioned in the answer to research question one.

Finally, as regards the transfer of $S A$, results are not clearcut. While participants scores in the error correction task apparently accounted for $46.1 \%$ of the variation in their scores in the $\mathrm{L} 2$ version of the task ( $F=6.83 p<.05)$, participants' scores in the L1 version of the error 
replication task were not unique predictors of their performance in the L2 task. As with the morphological association task, this might have happened due to the high scores participants had in the error replication task. Though the means for the Portuguese version was 6.8 and for the English one 6.55 (out of 10), in both languages, 63.6\% of participants (7 out of 11) got at least 7 answers correct.

Taking all that together, the answer to research question number two, which asked whether the participants' L1 level of metalinguistic awareness was a predictor of their L2 metalinguistic level, is also: in part. As mentioned above, it might be that there is a strong connection between all the three metalinguistic abilities in the 2 languages but that, due to some limitations in the instruments used for data collection, such connection was not always perceived. Another possibility is that, as Siegel (2000 in Francis, 2006) argued, perhaps systems such as syntax and morphology do not transfer so effortlessly across languages as is the case with phonology.

\subsection{L1 literacy, L1 and L2 metalinguistic awareness, and L2 proficiency}

Besides testing data collection instruments, the other main purpose of the present study was to establish a connection between L1 literacy and L2 proficiency. For that, a linear regression was run and the results show that participants' scores on the PISA test were unique predictors of their L2 proficiency test scores, accounting for $38.2 \%$ of the variation in the latter scores ${ }^{28}(F=5.55 p<.05)$. However, just finding that L1 literacy is a good predictor of L2 proficiency level does not tell us much about the nature of this relationship.

A case was built, throughout this paper, and following the suspicions of Tarone and Bigelow (2005), that one of the factors that might be implicated in the relationship between L1 literacy and L2 
proficiency is one's level of metalinguistic awareness. We also argued that, perhaps, as one's literacy level continues to develop, beyond the beginning alphabetization years, the level of metalinguistic awareness continues to increase (though probably in more subtle ways). I have also argued, based on empirical studies which found that metalinguistic awareness (mainly PA) transfers across languages, that perhaps, due to the transfer of L1 metalinguistic awareness to the L2, those with a higher level of L1 metalinguistic awareness would have an advantage when learning the second language.

As regards the first proposal, that literacy development "affects" one's level of metalinguistic awareness, the nature of the present study (cross-sectional and involving literate adults) does not allow us to reach any definite conclusions. To assess that, we would probably need to collect data from illiterates and later verify whether any growth in metalinguistic ability throughout, let's say, 10 years, could be predicted by their current level of L1 literacy. Moreover, to be certain that the difference in growth among participants was due to their having more and more experience with the written word, a control group of illiterates (with the same characteristics of the literate group) would have to contribute with data also. Since this was not possible in the present study, the option made was to verify statistically whether the participants' L1 literacy level was a good predictor of their performance in the L1 metalinguistic awareness tasks, which was presumed to be an indication of their level of L1 metalinguistic awareness. As already discussed when research question one was answered, the evidence found in the present paper does not allow for such conclusion.

As regards the possibility of transfer of metalinguistic awareness across languages, the results are more encouraging, since it was found that in at least one of the tasks of each of the abilities ${ }^{29}$ (and in the case 
of PA in both), participants' scores in the L1 task were good predictors of their performance in the L2 metalinguistic awareness task.

As a final attempt to clarify the link between L1 literacy and L2 proficiency level, linear regressions were made to verify whether participants' level of L1 and L2 metalinguistic awareness were good predictors of their level of L2 proficiency. It was thought that if the connection between literacy and proficiency passes through metalinguistic awareness, participants' scores in these tests should be good predictors of their scores in the L2 proficiency task.

Concerning L1 metalinguistic awareness, participants' scores in the morphological decision task and in the phonological transposition task showed to be good predictors of the participants' L2 performance, with the scores in the morphological decision task accounting for $38.7 \%$ of variation $(F=5.68 p<.05)$ and the scores on the phonological transposition task accounting for $40 \%$ of variation $(F=5.33 p<.05)$ in the participants' scores in the KET. The fact that neither the morphological association task scores nor the scores on the phonological segmentation task were good predictors is not surprising since these tasks seemed to be, respectively, too easy and too difficult for the participants. It is, nevertheless, interesting to notice that the participants' scores in neither of the SA tasks were significant predictors of L2 performance. Nevertheless, there was a tendency we believe is worth pointing out.

Though there was a tendency $(p=.07)$ for participants' scores in the error correction task to predict $34 \%$ of the variance in their L2 performance, if this relationship were, indeed, significant, the relationship would be a negative one since the gradient of the regression line was negative (-7.25). That is, the prediction would be that the more L1 SA a subject had, the worst would have been her/his performance in the test of L2 proficiency. At this point, this finding 
is simply puzzling since we have yet to find any studies which predict that higher levels of L1 metalinguistic ability are actually harmful for L2 learning. However, Swanson et al. (2008) did find negative correlations between L1 (Spanish) and L2 (English) measures of vocabulary, word identification, and pseudoword reading. Thus, it would be interesting to look further into this finding. Next, we turn to the relationship between L2 metalinguistic awareness and L2 performance.

Differently from what happened in relation to L1 SA, participants' scores on both measures of L2 SA proved to be good predictors of their L2 proficiency level. In the case of the error correction task, the linear regression showed that it can predict $76.9 \%(F=30.02$ $p<.05)$ of participants' scores in the L2 proficiency task. For the error replication task, the scores predicted $71.2 \%(F=22.19 p<$ $.05)$ of the KET scores. The reason why it is possible to have one variable predicting $76.9 \%$ of variance and a different one predicting "another" $71.2 \%$ is related to the statistical treatment given to the data. Since only linear regressions were used, each variable could be shown to account for up to $100 \%$ of variance in the outcome. With a hierarchical regression it would have been possible to predict how much variable $\mathrm{x}$, for example, can predict a given outcome after the impact of variable y has already been taken into consideration. In the case of variables that are too similar, as is the case in hand, probably the first one entered in the model would account for a great amount of variance and perhaps the other would not contribute with anything else. Nevertheless, if we think back about the nature of the KET, it is not surprising to find such a close connection. Much of what a grammaticality judgment task does is to assess the explicit knowledge of grammar rules and the kind of test KET is also has a very strong basis on the correct application of such rules. 
As regards the role L2 PA has in predicting L2 proficiency, once again the scores in the phonological segmentation task did not seem to contribute to the variance in the outcome. As argued previously, our suspicion is that this is due to the difficulty of the task, which might have prevented differences in this specific metalinguistic ability to emerge. For the phonological transposition task, however, its scores were found to contribute with $19.4 \%(F=2.17 p<.05)$ of the participants' variance in scores in the KET.

This time it was MA which did not show any contribution for the L2 proficiency scores. Indeed, though there have been no studies, to the best of our knowledge, which have found that MA contributes to L2 learning, one would expect that the knowledge of affixes, for example, and how they combine with roots to form new words, would help the development of one's L2 since this kind of knowledge has been shown to contribute with vocabulary learning. Deacon and Kirby (2004), for example, predicted that MA might be helpful in uncovering the meaning of single words. The example they give is that, if a person knows the root "read" and the affix "-ing" s/he may infer the meaning of "reading". Indeed, in their study and in Singson et al.s (2000), MA was found to make a contribution beyond that of PA for reading pseudowords (which can be argued to be quite similar to reading words in an L2). Additionally, in the L1, MA has been found to be significantly correlated to vocabulary knowledge (Mahony et al., 2000; Nagy et al., 2003).

Perhaps, once again, the test used to assess L2 MA were not adequate in the sense that the words used as stimuli in the MA tasks were not the kind of words one would expect beginning L2 students to be familiar with. Additionally, learners themselves mentioned that this task was easy in Portuguese because this is the kind of knowledge that formal schooling tends to cater to. Since they are beginning 
learners of English, it might be that they are not yet familiar with this kind of knowledge in the L2. An alternative explanation, of course, is that L2 MA did not play a role in the development of these learners' L2 competence.

Taking all the evidence discussed together, the answer to research question number three, which asked whether the participants' level of L1 literacy, L1 metalinguistic awareness, and/or L2 metalinguistic awareness could predict their L2 proficiency level is that the participants' L1 literacy level was a good unique predictor of their L2 performance. As concerns L1 and L2 metalinguistic awareness, the evidence does not offer a clearcut conclusion. Apparently, having more or less L1 and L2 metalinguistic knowledge does play a part in the development of one's L2 competence but exactly what abilities are the best predictors, and in which of the languages, cannot be established with the present evidence.

In the final section of this paper, we recap the results obtained and also point out the limitations of the present study, indicating how they could be overcome in future studies.

\section{Concluding remarks}

As stated above, although there have been a number of studies addressing the relationship between metalinguistic abilities (mainly PA) and literacy, so far research has concentrated mostly on the importance of metalinguistic awareness for literacy acquisition (and not vice-versa) and, thus, data has been usually collected from children and/or illiterate or little-literate participants and mostly using tasks in the L1 only. Thus, the first challenge in conducting a study where a link between L1 literacy, L1 and L2 metalinguistic awareness and L2 proficiency of literate adults is sought was to develop instruments that could be used with such population. And, 
since the present study took an exploratory lane, the next step was putting these instruments to use so as to verify whether there were, indeed, indications of the connections mentioned above.

The first issue we must mention is the fact that, since this was a pilot study and almost all tasks performed by the participants were developed for the purposes of the study, we have to look at the answers to the research questions bearing in mind the fact that at least some of the instruments used for data collection seem to be in need of adaptations so as to be better fit to assess the variables L1 literacy and L1 and L2 PA, MA, and SA. Apparently, some of the tasks used in the present study were too demanding and others not demanding enough for the population which contributed with data. For this reason, it is not possible to reach any firm conclusions concerning the relationship between L1 literacy and L2 proficiency or to precise whether metalinguistic awareness is mediating this connection. It is possible, however, to observe some trends that emerged from the data analysis.

In all the connections sought-between L1 literacy and L1 metalinguistic awareness, between L1 and L2 metalinguistic awareness, and between L1 literacy, L1 and L2 metalinguistic awareness and L2 proficiency-some relationship was found for at least one pair of variables. Taking that into consideration, and the fact that at least some of the tests seem to have been adequate in assessing the variables they were meant to be measuring, it can be claimed that this is, indeed, a fruitful avenue for investigation.

Besides the limitations regarding the instruments used for data collection, other factors do not allow for any definite conclusions to be drawn. First, the pool of participants is limited. Though the study is exploratory, a higher number of participants would certainly allow for a sounder statistical treatment of the data and, thus, lend more power 
to any conclusions that may be arrived at. Due to the small number of participants, it was not possible to run any statistical tests to assess the instruments' reliability, therefore conclusions have to be made based on the behavior and commentaries of the participants and on the observations of their raw scores. Due to time limitations, the data was not submitted to independent analyses and, thus, scores awarded to participants are subject to limitations and subjectivity. The ideal would be to have independent raters code at least part of the data.

Another limitation is in relation to the fact that the variables literacy and metalinguistic awareness were linked to L2 proficiency, rather than to L2 learning. Due to time constraints, participants only performed the L2 proficiency test once and, thus, a connection between L1 literacy level and L2 learning could not be made. Though a link between literacy and L2 performance is still interesting, it could be that a given learner has a higher proficiency level at the moment simply because $s /$ he has been studying the language for a longer period, has been using more efficient strategies, or has had a "better" teacher, for example. Only by looking at the participants' proficiency gains throughout a semester when they are exposed to (approximately) the same number of hours of instruction, with the same method, and (preferably) by the same teacher will it be possible to argue that, perhaps, one of the reasons why participant $\mathrm{A}$ has had more progress in this period than participant $B$ is due to him/her having higher levels of L1 literacy and/ or L1 metalinguistic awareness and/or L2 metalinguistic awareness. A final limitation is in relation to the statistical tool used to analyze the data-linear regression. The ideal would be for hierarchical regressions to be run so that it would be possible to verify how much each of the variables contribute to a given output, verifying whether the contribution of a given variable is not the result of relying on the same skills as another. 
The shortcomings of the present study are addressed in Xhafaj (forthcoming) who, by further scrutinizing the relationship between L1 literacy, metalinguistic awareness, and L2 learning, intends to determine whether a yet little-investigated variable-literacy-is also part of the complex equation involved in the learning of an L2.

\section{Notes}

1. In the present article we use the terms "learning" and "acquisition" interchangeably. The same also holds for the term "second" and "foreign" language.

2. See Dörnyei (2005) for a thorough discussion on individual differences that have been found to interact with L2 learning.

3. Here, we are using the term literacy as letramento, rather than alfabetização. This note is necessary due to the fact that the term literacy, in the literature written in English, is used to refer both to letramento and to alfabetização (though the term alphabetization does exist). In a very simplistic way, letramento could be defined as the social uses one makes of the written code in one's daily life (Kleiman, 1995). Our definition of literacy will be further discussed in the rationale section.

4. Koda (2007) defines metalinguistic awareness as "the ability to identify, analyze, and manipulate language forms” (p. 2).

5. A recast is "an immediate correct reformulation of a learner's erroneous utterance" (Bigelow et al., 2006, p. 669).

6. The term interlanguage is being used here as a synonym for the knowledge about the L2 system.

7. They justify their position by saying that even a person who has not been alphabetized but asks someone to read the newspaper/a book or to write a letter for her/him is somehow making use of the written code (Rogers, 2008; Soares, 1998).

8. We do not intend, here, however, to "ignor[e], demean, or... den[y] ... the existence of informal learning” (Rogers, 2008) just because we are focusing on formal learning. 
9. Programme for International Student Assessment. For more, see subsection 2.3 of the Method section.

10. For instance, Oliveira (1995), Olson (1977), Pauluk (2004), Torrance and Olson (1985), and Winchester (1985) predicted that the acquisition of literacy leads to a decontextualized kind of thought, where text and context were separated.

11. Unfortunately, this kind of research is often frowned upon since it presumes that the literate thought is not merely different from the oral but that it entails higher-order capacities which are only possessed by literates (Scribner \& Cole, 1978).

12. Though this might be due to the fact that the influence of morphological awareness (MA), which was found to play a greater role than PA in reading in Chinese, had already been partialled out when PA was entered into the equation.

13. However, the authors also suspect that this lack of difference might be due to the criterion (a non-standardized test) they used to divide their literate participants.

14. In the case of Nunes et al., they had a measure of morphological and syntactic awareness, something they called grammatical awareness, which would be the equivalent of what Correa (2005) terms consciência morfossintática. For a discussion on the possibility of assessing MA and SA separately, see Correa $(2005 ; 2009)$.

15. In another report of this same longitudinal study, Bryant et al. (2000) point out that MA scores were good predictors of spelling even 28 months after the MA data was collected.

16. Between 1 and 5\%. However, since prior learning was controlled for (the reading grades at the 2 nd grade) this probably means that the contribution of MA is greater since it probably had already contributed to the reading grade obtained at the beginning of the study.

17. In the stimuli, besides monomorphemic words-which could not be separated in meaningful parts-there were high- and low-saliency morphologically complex words. The high saliency were the ones which consisted of a prefix and a lexical base (e.g., re+solve) and the lowsaliency were the ones which were comprised of a prefix and a sublexical base (a Latinate) (e.g., in+clude). 
18. Actually, the test Ranta developed to assess L1 metalinguistic awarenessan error detection and correction task-was a test of SA and MA only.

19. Though if we look at the percentage of variance in reading and writing outcomes the metalinguistic abilities tend to explain in the L1, we would not say that this is such a disappointing result.

20.h t t p : / / w w w. o e cd.org/d ocument/53/0,2340, en_32252351_32235731_38262901_1_1_1_1,00.html\#Background_ and_basics) retrieved on July, 2009.

21. Some of the questions used in the PISA evaluations are used over and over in different editions and, thus, cannot be made public. Nevertheless, OECD publishes all the other questions that will not be used again.

22. A thorough description of the testing procedures can be found at http:// www.cambridgeesol.org/assets/pdf/resources/teacher/ket_handbook. pdf.

23. Related to gender (in the case of Portuguese only) and number agreement for nouns and also tense/mood and number agreement for verbs (Mota, Lisboa et al., 2008).

24. Related to word formation (adding suffixes and prefixes) or word decomposition (deleting suffixes and prefixes to arrive at the root of a word).

25. Correa (2005) defends that what have been commonly termed tests of SA, should be actually named tests of morphosyntactic awareness since the morphological component is often part of such tests.

26. That is, finding that the participants' level of L1 literacy was not a good predictor of their level of L1 metalinguistic awareness does not mean that these variables are not, somehow, related. It might be that it better to verify a simple correlation between the variables, rather than a directional relationship.

27. One participant left 3 blank questions, 4 left from 7 to 11 blank questions, and one left 22 blank questions.

28. Though the evidence is encouraging, it is wise to keep in mind the fact that the measure used to assess L1 literacy had limitations and, thus, the numbers derived from it might be misleading. 
29. Though for MA significance was only approached $(\mathrm{p}=.055)$.

Authors' Note: The authors would like to thank the Conselho Nacional de Desenvolvimento Científico e Tecnológico (CNPq) for funding the present research as well as Drs. Márcia da Mota and Rosane Silveira for their contributions to an earlier version of this article.

\section{References}

Alves, P. F. (2008). A consciência morfossintática na aprendizagem do simple present por alunos falantes do português brasileiro. Unpublished Master's thesis, Programa de Pós-graduação em Letras, Pontifícia Universidade Católica do Rio Grande do Sul, Porto Alegre.

Barrera, S. \& Maluf, M.R. (2003). Consciência metalingüística e alfabetização: um estudo com crianças da primeira série do ensino fundamental. Psicologia: reflexão e crítica, 16(3), 491-502.

Bialystok, E. (2007). Acquisition of literacy in bilingual children: a framework for research. Language learning, 57(1), 45-77.

Bialystok, E., \& Herman, J. (1999). Does bilingualism matter for early literacy? Bilingualism: language and cognition, 2(1), 35-44.

Bialystok, E., Luk, G., \& Kwan, E. (2005). Bilingualism, biliteracy, and learning to read: interactions among languages and writing systems. Scientific studies of reading, 9 (1), 43-61.

Biber, D. (2009). Are there linguistic consequences of literacy? Comparing the potentials of language use in speech and writing. In D. Olson \& N. Torrance (Eds.), The Cambridge Handbook of Literacy (pp. 75- 91). New York: Cambridge University Press.

Bigelow, M., Delmas, R., Hansen, K., \& Tarone, E. (2006). Literacy and the processing of oral recasts in SLA. TESOL Quarterly, 40 (4), 665-689.

Bowey, J. A. (2005). Grammatical sensitivity: Its origins and potential contribution to early word reading skill. Journal of Experimental Child Psychology, 90(4), 318- 343.

Bryant, P., Nunes, T., \& Bindman, M. (2000). The relations between children's linguistic awareness and spelling: The case of the apostrophe. Reading and Writing: An Interdisciplinary Journal, 12, 253-276. 
Bryant, P., Nunes, T., \& Bindman, M. (1997). Children's understanding of the connection between grammar and spelling. In B. Blachman (Ed.), Foundations of reading acquisition and dyslexia: Implications for early intervention (pp. 219-240). Mahwah, NJ: Erlbaum.

Cain, K. (2007). Syntactic awareness and reading ability: is there any evidence for a special relationship? Applied psycholinguistics, 28, 679694.

Capovilla, A.G.S., Capovilla, F.C., \& Soares, J.V.T. (2004). Consciência sintática no ensino fundamental: correlações com consciência fonológica, vocabulário, leitura e escrita. Psico-USF, 9 (1), 39-47.

Capovilla, A.G.S., Dias, N. M., \& Montiel, J. M. (2007). Desenvolvimento dos componentes da consciência fonológica no ensino fundamental e correlação com nota escolar. Psico, 12 (1), 55-64.

Caravolas, M., Volín, J., \& Hulme, C. (2005). Phoneme awareness is a key component of alphabetic literacy skills in consistent and inconsistent orthographies: Evidence from Czech and English children. Experimental child psychology, 92, 107-139.

Carlisle, J.F. (2006). Morphological processes that influence learning to read. In C. A. Stone, E. R. Silliman, B. J. Ehren, \& K. Apel (Eds.), Handbook of language \& literacy: development and disorders (pp. 318- 339). New York: The Guildford Press.

Carlisle, J.F., Beeman, M. M., Davis, L. H., \& Spharim, G. (1999). Relationship of metalinguistic capabilities and reading achievement for children who are becoming bilingual. Applied Psycholinguistics, 20, 459-478.

Cerutti-Rizzatti, M.E. (2009). Sociocognição e língua escrita: uma discussão sobre implicações das fronteiras do conceito de letramento. Unpublished manuscript.

Cheung, H., Chen, H., Lai, C.Y., Wong, O.C., \& Hills, M. (2001). The development of phonological awareness: effects of spoken language experience and orthography. Cognition, 81, 227-241.

Chikamatsu, N. (1996). The effects of L1 orthography on L2 Japanese word recognition. Studies in Second Language Acquisition, 18, 403-432. 
Cisero, C.A., \& Royer, J.M. (1995). The development and cross-language transfer of phonological awareness. Contemporary Educational Psychology, 20, 275-303.

Correa, J. (2009). Habilidades metalinguísticas relacionadas à sintaxe e à morfologia. In M. Mota, (Ed.) Desenvolvimento metalingüístico: questões contemporâneas (pp. 55-76). São Paulo: Casa do Psicólogo.

Correa, J. (2005). A avaliação da consciência morfossintática na criança. Psicologia: Reflexão e Crítica, 18 (1), 91-97.

Cunha, V.L.O., \& Capellini, S.A. (2009). Prohmele-Provas de habilidades metalingüísticas e de leitura. Rio de Janeiro: Revinter

Deacon, S.H., \& Kirby, J.R. (2004). Morphological awareness: just "more phonological"? The roles of morphological and phonological awareness in reading development. Applied psycholinguistics, 25, 223-238.

Dellatolas, G., Braga, L.W., Souza, L.N., Nunes Filho, G., Queiroz, E., \& Deloche, G. (2003). Cognitive consequences of early phase of literacy. Journal of the International Neuropsychological Society, 9, 771-782.

Dias, N.M. (2006). Alfabetização fônica computadorizada: usando o computador para desenvolver habilidades fônicas e metafonológicas. Revista Semestral da Associação Brasileira de Psicologia Escolar e Educacional (ABRAPEE), 10 (1), 149-152.

Dörnyei, Z. (2005). The psychology of the language learner: individual differences in second language acquisition. Mahwah: Laurence Erlbaum Associates

Doughty, C., \& Long, M. (2003). The scope of inquiry and goals of SLA. In C. Doughty \& M. Long (Eds.), The handbook of second language acquisition (pp. 3-16). Oxford: Blackwell Publishing.

Dufva, M., \& Voeten, M.J.M. (1999). Native language literacy and phonological memory as prerequisites for learning English as a foreign language. Applied psycholinguistics, 20, 329-348.

Durgunoğlu, A.Y. (2002). Cross-linguistic transfer in literacy development and implications for language learners. Annals of Dyslexia, 52, 189-204.

Durgunoğlu, A.Y., Nagy, W.E., \& Hancin-Bhatt, B.J. (1993). Cross-language transfer of phonological awareness. Journal of Educational Psychology, $85,453-465$. 
Ehri, L. (1985). Effects of printed language acquisition on speech. In D.R. Olson, N. Torrance \& A. Hildyard (Eds.), Literacy, language, and learning: The nature and consequences of reading and writing (pp. 333367). New York: Cambridge University Press.

Ellis, R. (2008). The study of second language acquisition. $2^{\text {nd }}$ edition. Oxford: Oxford University Press.

Francis, N. (2006). The development of secondary discourse ability and metalinguistic awareness in second language learners. International Journal of Applied Linguistics, 16, 37-60.

Ganschow, L., \& Sparks, R. (1995). Effects of direct instruction in Spanish phonology on the native-language skills and foreign-language aptitude of at-risk foreign-language learners. Journal of learning disabilities, 28(2), 107-120.

Genesee, F., Lindholm-Leary, K., Saunders, W.M., \& Christian, D. (2006). Educating English language learners: a synthesis of research evidence. Cambridge: Cambridge University Press.

Godoy, D. M (2005). Aprendizagem inicial da leitura e da escrita no português do Brasil: influência da consciência fonológica e do método de alfabetização. Unplublished doctoral dissertation, Programa de PósGraduação em Linguística, Universidade Federal de Santa Catarina, Florianópolis.

Gottardo, A., Yan, B., Siegel, L. S., \& Wade-Woolley, L. (2001). Factors related to English reading performance in children with Chinese as a first language: More evidence of cross-language transfer of phonological processing. Journal of Educational Psychology, 93 (3), 530-542.

Guimarães, S. R. K. (2003). Dificuldades no desenvolvimento da lecto-escrita: o papel das habilidades metalinguísticas. Psicologia: Teoria e Pesquisa, 19 (1), 33-45.

Hamada, M., \& Koda, K. (2008). Influence of First Language Orthographic Experience on Second Language Decoding and Word Learning. Language Learning, 58 (1), 1-31.

Harley, B., \& Hart, D. (2002). Age, aptitude and second language learning on a bilingual exchange. In P. Robinson (Ed.), Individual differences and instructed language learning (pp. 301-330). John Benjamin 
Holm, A., \& Dodd, B. (1996). The effect of first written language on the acquisition of English literacy. Cognition, 59, 19-147.

Jongean, W., Verhoeven, L., \& Siegel, L.S. (2007). Predictors of reading and spelling abilities in first- and second-language learners. Journal of educational psychology, 99(4), 835-851.

Juel C., Griffith P. L. \& Gough P. B. (1986) Acquisition of literacy: A longitudinal study of children in first and second grade. Journal of Educational Psychology, 78, 243-255.

Kato, M.A. (1993). No mundo da escrita: uma perspectiva psicolingüística. São Paulo: Editora Ática.

Kleiman, A. B. (1995). Modelos de letramento e as práticas de alfabetização na escola. In A. B. Kleiman (Ed.), Os significados do letramento: uma nova perspectiva sobre a prática social da escrita (pp. 15-61). Campinas: Mercado das Letras.

Koda, K. (2007). Reading and language learning: Crosslinguistic constraints on second language reading development. Language Learning, 57, 1-44.

Koda, K. (2000). Cross-linguistic variations in L2 morphological awareness. Applied psycholinguistics, 21, 297-320.

Kosmidis, M.H., Tsapkini, K., Folia, V., Vlahou, C.H., \& Kiosseoglou, G. (2004). Semantic and phonological processing in illiteracy. Journal of the International Neuropsychological Society, 10, 818-827.

Lasch, S.S. (2008). Estudo comparativo da consciência fonológica de crianças com aquisição bilíngüe e monolingüe da linguagem. Unpublished Master's thesis, Programa de Pós-graduação em distúrbios da comunicação humana, Universidade Federal de Santa Maria, Santa Maria.

Lazo, M. G., Pumfrey, E D., \& Peers, I. (1997). Metalinguistic awareness, reading, and spelling: Roots and branches of literacy. Journal of Research in Reading, 20(2), 85-104.

Long, M. (1991). Focus on form: A design feature in language teaching methodology. In K. de Bot, R. Ginsberg, \& C. Kramsch (Eds.), Foreign language research in cross-cultural perspective (pp. 39-52). Amsterdam: Benjamins. 
Loureiro, C.S., Braga, L.W., Souza, L.N., Nunes Filho, G., Queiroz, E., \& Dellatolas, G. (2003). Degree of illiteracy and phonological and metaphonological skills in unschooled adults. Brain and Language, 89, 499-502.

Mahony, D., Singson, M., \& Mann, V. (2000). Reading ability and sensitivity to morphological relations. Reading and Writing: An Interdisciplinary Journal, 12, 191-218.

Mann, V. (1986). Phonological awareness: The role of reading experience. Cognition, 24, 65-92.

Marchetti, P.T. (2008). Desempenho em consciência fonológica de crianças com desenvolvimento fonológico normal e desviante e a terapia fonológica. Unpublished Master's thesis, Programa de Pós-graduação em distúrbios da comunicação humana, Universidade Federal de Santa Maria, Santa Maria.

McBride-Chang, C., Cho, J.R., Liu, H, Wagner, R.K., Shu, H., Zhou, A. et al. (2005). Changing models across cultures: associations of phonological awareness and morphological awareness structure with vocabulary and word recognition in second graders from Beijing, Hong Kong, Korea, and the United States. Journal of experimental child psychology, 92, 140160 .

Meschyan, G., \& Hernandez, A. (2002). Is native-language decoding skill related to second-language learning? Journal of educational psychology, 94(1), 14-22.

Morais, J., Bertelson, P., Cary, L., \& Alegria, J. (1986). Literacy training and speech segmentation. Cognition, 24, 45-64.

Mota, M.M.P.E (2008). Considerações sobre o papel da consciência morfológica nas dificuldades de leitura e escrita: uma revisão da literatura. Psicologia Escolar e Educacional, 12 (2), 347-355.

Mota, M.M.P.E. (2007). Algumas considerações sobre o letramento e o desenvolvimento metalingüístico e suas implicações educacionais. Estudos e pesquisas em psicologia, 7 (3), 118-130.

Mota, M.M.P.E., Anibal, L., \& Lima, S. (2008). A morfologia derivacional contribui para a leitura e escrita no português? Psicologia: Reflexão $e$ Crítica, 21(2), 311-318. 
Mota, M.M.P.E., \& Castro, N.R. (2007). Alfabetização e consciência metalingüística: um estudo com adultos não alfabetizados. Estudos de Psicologia, 24(2), 169-179.

Mota, M.M.P.E, Gontijo,R., Mansur-Lisboa, S., Olive, R., Silva, D., Dias, J. et al. (2008). Avaliação da consciência da morfologia derivacional: Fidedignidade e validade. Avaliação Psicológica, 7(2), 151-157.

Mota, M.M.P.E, Lisboa, R., Dias, J., Gontijo, R., Paiva, N., Mansur-Lisboa, S. et al. (2008). Morfologia derivacional e alfabetização. Retrieved on January, 23, 2010 from http://www.uff.br/virtu/files/2010/05/5a-6.pdf

Nagy, W., Berninger, V.W., \& Abbot, R.D. (2006). Contributions of morphology beyond phonology to literacy outcome of upper elementary and middle-school students. Journal of Educational Psychology, 98(1), 34-147.

Nagy, W., Berninger, V., Abbott, R., Vaughan, K., \& Vermeulen, K. (2003). Relationship of morphology and other language skills to literacy skills in at-risk second grade readers and at-risk fourth grade writers. Journal of Educational Psychology, 95(4), 730-742.

Nation, K., \& Snowling, M.J. (2000). Factors influencing syntactic awareness skills in normal readers and poor comprehenders. Applied psycholinguistics, 21, 229-241.

Nunes, T., Bryant, P.E., \& Bindman, M. (1997) Morphological spelling strategies: developmental stages and processes. Developmental Psychology, 33, 637-649.

Oliveira, M.K. (1995). Letramento, cultura e modalidades de pensamento. In A.B. Kleiman (Ed.), Os significados do letramento: uma nova perspectiva sobre a prática social da escrita (pp. 147-160). Campinas: Mercado de Letras.

Oliveira, R.A.M., \& Oliveira, K.L. (2007). Leitura e condições de estudo em universitários ingressantes. PSIC - Revista de Psicologia, 8 (1), 51-59.

Olson, D. (1977). From utterance to text: the bias of language in speech and writing. Harvard Educational Review, 47 (3), 257-281.

Organization for Economic Co-operation and Development (OECD). Programme for international student assessment of reading, mathematical 
and scientific literacy. Retrieved on February, 27, 2009 from http://www. oecd.org/dataoecd/44/62/33692744.pdf

Pauluk, M. (2004). Um novo olhar sobre a escrita: a contribuição das ciências cognitivas e da semiótica para o desenvolvimento de uma ciência da escrita. Ciências \& Cognição, 02, 02-10.

Pereira, J. (2008). O desenvolvimento da consciência fonológica e o processamento em crianças da última série do ensino infantil. Unpublished Master's thesis, Programa de Pós-graduação em Lingüística, Universidade Federal do Rio de Janeiro, Rio de Janeiro.

Perfetti, C.A., Dyke, J.V., \& Hart, L. (2001). The psycholinguistics of basic literacy. Annual Review of Applied Linguistics 21, 127-149.

Pestun, M.S.V. (2005). Consciência fonológica no início da escolarização e o desempenho ulterior em leitura e escrita: estudo correlacional. Estudos de Psicologia-Natal, 10(3), 407-412.

Plaza, M., \& Cohen, H. (2004). Predictive influence of phonological processing, morphological/syntactic skill, and naming speed on spelling performance. Brain and Cognition, 55, 638-373.

Ranta, L. (2002). The role of learners' language analytic ability in the communicative classroom. In P. Robinson (Ed.), Individual differences and instructed language learning (pp.159-180). John Benjamins.

Ravid, D., \& Tolchinsky, L. (2002). Developing linguistic literacy: a comprehensive model. Journal of Child Language, 29, 417-447.

Read, C., Yun-Fei, Z., Hong-Yin, N., \& Bao-Qing, D. (1986). The ability to manipulate speech sounds depends on knowing alphabetic writing. Cognition, 24(1-2), 31-44.

Rego, L.L.B. (1995). Diferenças individuais na aprendizagem inicial da leitura: papel desempenhado por fatores metalingüísticos. Psicologia: Teoria e Pesquisa, 11, 51-60.

Rego, L.L.B., \& Buarque, L.L. (1987). Consciência sintática, consciência fonológica e aquisição de regras ortográficas. Psicologia: Reflexão e Crítica, 10 (2), 199-217.

Reis, A., \& Castro-Caldas, A. (1987). Illiteracy: a bias for cognitive development. Journal of the International Neuropsychological Society, 3, 444-50. 
Richards, J.C., Hull, J., \& Proctor, S. (2004). Interchange: Third edition. Cambridge: Cambridge University Press.

Riches, C., \& Genesee, F. (2006) Cross-linguistic and cross-modal aspects of literacy development. In F. Genesee, K. Lindholm-Leary, W. Saunders, \& D. Christian, D.(Eds.), Educating English language learners: A synthesis of research evidence (pp. 64-108). New York: Cambridge University Press.

Rogers, A. (2008). Informal Learning and Literacy. In B. Street \& N. H. Hornberger (Eds.), Encyclopedia of Language and Education, 2nd Edition, Volume 2: Literacy, (pp. 1-12). Springer Science, Business Media LLC.

Rojo, R. (2009). Letramentos múltiplos: escola e inclusão social. São Paulo: Parábola.

Schmidt, R. (1990). The role of consciousness in second language learning. Applied Linguistics, 11, 129-158.

Schwartz, M, Share, D.L., Leikin, M., \& Kozminsky, E. (2007). On the benefits of bi-literacy: just a head start in reading or specific orthographic insights? Reading and Writing: an interdisciplinary journal, 21(9), 905927.

Scribner, S., \& Cole, M. (1978). Literacy without schooling: testing for intellectual effects. Harvard Educational Review, 48 (4), 448-461.

Singson, M., Mahony, D., \& Mann, V. (2000). The relation between reading ability and morphological skills: Evidence from derivational suffixes. Reading and Writing: An Interdisciplinary Journal, 12, 219-252.

Soares, M. (1998). Letramento: um tema em três gêneros. Belo Horizonte: Autêntica.

Souza, E.C., \& Bondini, H.H.M. (2007). Programa de treinamento de consciência fonológica para crianças surdas bilíngües. Paidéia, 17(36), 123-135.

Sparks, R., \& Ganschow, L. (1993). Searching for the cognitive locus of foreign language learning difficulties: linking first and second language learning. The modern language journal, 77, 289-302. 
Sparks, R., \& Ganschow, L. (1991). Foreign language learning differences: affective or native language aptitude differences? The modern language journal, 75(1), 3-16.

Sparks, R., Artzer, M., Ganschow, L., Siebenhar, D., Plageman, M., \& Patton, J. (1998). Differences in native-language skills, foreign-language aptitude, and foreign-language grades among high-, average-, and lowproficiency foreign-language learners: two studies. Language testing, 15(2), 181-216.

Sparks, R., Ganschow, L., Javorsky, J., Pohlman, J., \& Patton, J. (1992). Tests comparisons among students identified as high-risk, low-risk, and learning disabled in High School Foreign Language courses. The modern language journal, 76(2), 142-159.

Sparks, R., Patton, J., Ganschow, L., Humbach, N., \& Javorsky, J. (2008). Early first-language reading and spelling skills predict later secondlanguage reading and spelling skills. Journal of educational psychology, 100(1), 162-174.

Swanson, H. L., Rosston, K., Gerber, M., \& Solari, E. (2008). Influence of oral language and phonological processing on children's bilingual reading, Journal of School Psychology, 46, 413-429.

Tarone, E., \& Bigelow, M. (2005). Impact of literacy on oral language processing: Implications for second language acquisition research. Annual Review of Applied Linguistics, 25, 77-97.

Tarone, E., Bigelow, M., \& Swierzbin, B. (2007). Impact of literacy level on features of interlanguage in oral narratives. Rivista de psicolinguistica applicata VI, 3, 65-77.

Terra, M. R. (2009). Letramentos em língua materna \& relações de plurilinguismo na aula de inglês. Unpublished doctoral dissertation, Programa de pós-graduação em lingüística aplicada, Universidade Estadual de Campinas, Campinas.

Tfouni, L. V. (1995). Escrita, alfabetização e letramento. In L.V.Tfouni (Ed.), Letramento e alfabetização (pp. 9-28). São Paulo: Cortez

Torrance, N., \& Olson, D.R. (1985). Oral and literate competencies in the early school years. In D.R. Olson, N. Torrance \& A. Hildyard (Eds.), 
Literacy, language, and learning: The nature and consequences of reading and writing (pp. 256-284). New York: Cambridge University Press.

Verhoeven, L.T. (1994). Transfer in bilingual development: The linguistic interdependence hypothesis revisited. Language Learning, 44, 381-415.

Wagner, R.K., Torgesen, J.K.,\& Rashotte, C.A. (1994). Development of reading related phonological processing abilities: New evidence of bi-directional causality from a latent variable longitudinal study. Developmental Psychology, 30, 73-87.

Winchester, I. (1985). Atlantans, centaurians, and the litron bomb: some personal and social implications of literacy. In D.R. Olson, N. Torrance \& A. Hildyard (Eds.) Literacy, language, and learning: The nature and consequences of reading and writing (pp. 34-49). New York: Cambridge University Press. 
